\title{
THE NEW WAVE OF CURRENCY DEVALUATIONS IN AFRICA - UILL THE DEVALUED BIRR HELP THE COFFEE EXPORTS?
}

\author{
SZABOLCS PASZTOR \\ NATIONAL UNIVERSITY OF PUBLIC SERVICE
}

Despite the fact that currency devaluations are likely to have a negative effect on the economy in the long run, Ethiopia devalued its national currency, the birr (ETB), by 15 percent in 2017. They turned to this option in the hope of attracting more investments from abroad, decreasing import bills, improving the current account deficit and giving a boost to the exports of the coffee sector. A couple of months later, the impact seems to be promising because the export has been revived in some areas. However, it has to be stressed that the imported commodities may experience a price increase, there can be a widening balance of payments deficit and rising inflation. The paper aims to shed more light on the short- and long-term impacts of currency devaluations in the developing countries with a special emphasis on Ethiopia. Also, the recent Ethiopian measure is to be analyzed in greater detail highlighting the impacts on export earnings, import bills, the balance of payments, and on the overall competitiveness of the coffee sector.

\section{Currency depreciations and devaluations in Africa}

Recently, most of the African countries have suffered from significant currency instabilities. The reasons are quite obvious as the strength of the African currencies is closely related to raw material prices. These prices have faced huge volatility since mid-2014 and the global demand for commodity exports has weakened remarkably. We also have to mention China registering much flatter growth rates than before. In this context, African central banks face multiple challenges related to exchange rates. Among others, we can mention Mozambique's metical (MZN) which fell by well over 30\% against the US dollar in 2016. The Angolan kwanza (AOA) lost almost $20 \%$ of its value. The Guinean and Congolese francs (GNF and CDF) weakened significantly, by $18 \%$ and $21 \%$. The leone in Sierra Leone (SLL) depreciated by $27 \%$ in 2016. Nigeria is also an interesting case, as the naira (NGN) almost collapsed and weakened by a third just after the government removed its peg to the USD in June 2016. The Zambian kwacha (ZMK) depreciated by over $40 \%$ in 2015 becoming the third-worst performing currency in the world. The Exchange Market Pressure Index (EMPI) developed by Girton and Roper (1977) reflects increased tensions in the 
foreign exchange market. The exchange rate risk is still relevant in Africa which is confirmed by the depreciation of the AOA by more than 30 percent since the partial liberalization of the exchange rate regime in January 2018 (Nizard, 2018).

African countries registering lower levels of exports of raw materials have seen their inflows of US dollars diminished. As a number of local currencies are highly dependent on the USD, the impact on the stability is far from promising. The macroeconomic stability of the sub-Saharan region has also seen better days as the oil exporters maintained a fiscal deficit of over 5 percent in 2017 (IMF, 2018). This and a couple of other factors dent the confidence of the investors in the economies and in the local currencies. The rising inflation rate is also a huge concern as it was hovering around 20 percent in Mozambique, Sierra Leone, and Nigeria in 2016. In some countries (e.g., Angola, Congo, Central African Republic), it reached almost 40 percent (IMF, 2018).

Weaker local currencies are mostly detrimental as they increase the local prices for consumer products and make the prices of machinery and capital goods more expensive for infrastructure developments. Under these pressures, central banks face very difficult challenges: in the hope of mitigating the impact of inflation, (i) they can turn to raising interest rates (ii) or they may choose to keep the inflation rate low and maintain the growth prospects. (iii) At this time, the positive impact of currency depreciation is not an option, as owing to the reduced demand in world markets, they cannot count on the boosting effect. (iv) Most of the central banks have run out of foreign currency reserves as they were partly financing the rising import costs and maintained the local exchange rates, not to mention servicing the increasing external debt obligations. In this context, more and more central banks are doing research on devaluation or they let the local currency depreciate. Some have already turned to devaluation (e.g., Sudan, Ethiopia) and their reasoning is clear: they want to attract more investors and they also want to give a boost to the export sector of the economy. An issue which has been debated for decades.

\section{Theoretical framework}

Apart from the fact that both devaluation and depreciation indicate altered values in terms of other currencies, they are not the same. So, first of all, we have to give an appropriate definition for the terms of devaluation and depreciation in order to fully understand their impacts on the economy.

Devaluation is a deliberate reduction of the value of a country's currency relative to another currency or currencies. The opposite of devaluation is revaluation. Devaluation is a monetary policy tool of those countries and central banks which have a fixed or semi-fixed exchange rate system. Contrary to devaluation, depreciation is caused by market forces making the local currency less and less valuable. While devaluation is a one-time measure taken by the central bank, depreciation is a gradual change. However, in international economics, it always takes time for the changed exchange rate to have a clear effect on the patterns of international trade (Meade, 1988; Backus et al., 1994). It is already confirmed that after large devalua- 
tions there is sluggishness in exports, partly because the most powerful response happens with a lag of three or four years. This lag comes mainly from the costs that producers face to adjust the markets or customers that they want to serve. It is also true that the export response can be hampered as financing export expansion is worsened by the devaluation (Manova, 2013).

When studying the theoretical framework of devaluation, it becomes clear that there are three different approaches. According to the first, the monetarist approach (Dornbusch, 1973; Miles, 1979), devaluation changes the relative price of traded and non-traded products which leads to the improvement of the trade balance and the balance of payments. They claim that the real supply of money decreases, an excess demand for money is reached and actually the ensuing hoarding effect improves the trade balance.

According to the absorption approach, if a country has a balance of payments deficit, consumers are 'absorbing' more than what they produce. Devaluation changes the terms of trade, increases production and shifts spending from import to local goods. Trade balance is improved as the domestic absorption relative to production is reduced (Johnson, 1967).

According to the elasticity approach, transactions might dominate a short-term change in the trade balance which results in deterioration (Krueger, 1983). Later, in the long run, exports and imports adjust causing an elasticity increase of exports, imports, and their quantities. The price of the devaluing country's exports is lowered and, at the same time, both the price of the imported goods and their demand are increased. It is clear that the real effect of devaluation depends on the elasticity of exports and imports. Higher import prices may give a boost to domestic production and later lead to price increases of the non-traded goods. The obvious effect is inflation and the potential benefit of devaluation is diminished (Williamson, 1983). The Marshal-Lerner (ML) condition gives a further solid analytical ground for the elasticity approach and it is built on the following assumptions: (i) partial equilibrium, (ii) the price elasticity of supply in the home country and abroad is infinite, (iii) the monetary effects of exchange rate variations are ignored, and (iv) an initial balance of trade is assumed. If the Marshall-Lerner conditions are satisfied, devaluation can improve the trade balance and the GDP in the long run.

Based on the three approaches, it is quite clear that devaluation has ambiguous results in growth. The positive aspects include the followings. The Keynesian approach emphasizes the expansionary effects of devaluation to output and growth. Namely, devaluation stimulates the demand and output and the expansionary effect 
is reached by expenditure switching and reduction in domestic consumption. As it has been already mentioned, when the Marshall-Lerner condition is met, devaluations can be positive. At firm level, when a currency is devalued, profit made by local companies producing in foreign markets increases after converting it to the national currency. Paul (2006) and Gala (2007) highlights that this increased profit can be used for research and development and innovations. However, it is also true that when there is less competition, devaluation can make firms unmotivated and the consequence would be no significant effect on the economy in the long run (Erixon, 2007). Acar (2000) points to the issue of wage indexation. In case of a price increase resulting from devaluation, the real wage falls and the producers will be pressurized to increase the wage rate to retain the workers or offer them a decent standard of living. This will directly lead to the decreasing profit of producers.

Apart from these positive or mixed aspects, Krugman and Taylor (1978) point to the definitely negative effects of currency devaluations on economic growth. They argue that devaluation would increase the profit share of GDP with the negative effect of aggregate demand if the saving propensity of firms and capital owners is higher than that of wage owners. Countries being highly dependent on the nontradable sector ${ }^{1}$ will experience a negative impact as the distribution of the exposed and the non-exposed sectors is not the same and the non-exposed sector and the total output growth would be negatively affected (Goldberg, 1990). Owing to the increasing inflation, interest rates may be raised also, leading to decreasing aggregate demand finally. Local companies borrowing from commercial banks to finance their operations will be also negatively affected, not to mention servicing the government debt. It has to be highlighted also that anticipated and unanticipated devaluations may have different effects on the long-term growth of the economy.

When analyzing exact countries and their devaluations, the answers are still mixed (An et al., 2014) but there are some unquestionable facts. Imoisi (2012), for example, focused on interest rates, the balance of payments, and the relationship between exchange rates and pointed to a significant relationship between the three variables. Reinhart (1995) took into consideration the relative price and its trade effect and made the following conclusions: (i) relative prices are important determinants of the demand for imports and exports, (ii) price elasticities are usually low and they are below unity, and (iii) relative prices and a sufficient level of income are both necessary for steady trade flows.

As far as exact countries or group of countries are concerned, Acharya (2010), for example, when studying the Nepalese case, argued that devaluation increases the price of import and, as a consequence, leads to a higher production of export products in the agricultural and industrial sectors. He also pointed to the fact that the industrial sector expands and the service and agricultural sectors shrink. The final outcome is an overall GDP growth, owing to the increasing production of the industrial sector. Acar (2000) studied 18 LDCs with very different export performances. In the first year, he found a negative relationship between devaluation and output. In the next year, a positive effect was confirmed, while in the long run, no 
effect was measured. Akinlo (1996) focused on Nigeria and concluded that negative relationship existed between the profit levels of manufacturing industries and exchange rate movements: the higher the exchange rate depreciation is, the lower the rates of profit are. Another African country, Cameroon was also studied by Tybout et al. (1997). Firms already involved in international trade increased their exports, while non-exporting firms started staying away from international markets because of increasing costs. Ratha (2010) confirms the Keynesian positive aspect of devaluations and the multiplier effect on export and GDP growth. The results were not promising in the short run, but in the long run, the expansionary effects were clear. A study on Fiji confirmed the positive impact of devaluation when it pointed to a 2.3 percent and 3.3 percent increase in the output in the short and long run as well. Related to Ethiopia, Taye (1999) argues that devaluation would help improve the current account balance but would be stagflationary. The improvement in the current account balance is, therefore, more likely due to a decrease in imports (expenditure reducing, not expenditure switching) and not due to an expansion in output and hence exports. In the case of a small, open economy, Musila and Newark (2003), based on evidence from Malawi, claimed that the devaluation might help improve export performance and mitigate the growth of imports in the long run. However, in the case of Africa and the Middle East, where export is highly reliant on primary commodities, the impact of devaluation is negligible. Al-Abdelrazag (1997), for example, examined the Jordanian economy and argued that the devaluation did not improve the trade balance as the sum of demand elasticities for imports and exports were less than one. Zaidan (1999) argues that developed country elasticities are much higher than in the case of developing countries. Other studies are also far from being optimistic. Agénor (1991) took into consideration 23 countries and he pointed to the fact that the expected devaluation had contradictory effects. Edwards (1986) studied 12 developing countries and confirmed that the devaluation of the exchange rate in the same year had a negative effect. One year later the effect proved to be positive and, in the long run, the conflicting effects resulted in a zero-sum game. Mehare and Edriss (2013) argues that devaluation may play a certain role in eliminating market distortions and correcting price misalignment in the short term. However, in the long run, in the case of Ethiopia, devaluation has a negative impact on the export of agricultural products. Their argumentation is clear as they make a differentiation between the short-term and long-term impacts. In the short term, exporters benefit and increase their export volumes, but given the fact that agricultural products have an inelastic nature of demand, the price increase in the world markets will finally disappear and the local market prices will be higher than the international ones so the companies will be less and less incentivized to export. In this way, devaluation would have an opposite effect compared to that in the short run. According to the theory of deteriorating terms of trade; for an agrarian economy, export revenues from primary commodities are likely to remain the same or drop after a certain period of time. Imports continue to rise and the two effects together widen the balance of payment deficit. 
Apart from these mixed results, many developing countries still use currency devaluation as a tool to achieve short- and long-term growth objectives and they do not always bear in mind that the effect of devaluation depends on the followings. (i) The elasticity of demand for exports and imports. If the demand is price-inelastic, a fall in the price of exports will not lead to a large rise in quantity leading to a fall in the value of exports. If the price elasticity of exports and imports is more than one, devaluation may improve the trade balance. It is also true that the effect of devaluation comes with a time-lag, as in the short run, demand might be inelastic but, in the long run, it might become elastic with a bigger effect. (ii) The overall state of the world economy is also important. In case of global recessions, devaluation can be insufficient to stimulate export demand. In case of a boom, there is greater demand but it can also exacerbate inflation in the devaluing economy. (iii) Inflation is a crucial factor as it may have different effects. In case of recessions in the local economy, when there is spare capacity, devaluation is unlikely to lead to inflation. Companies may reduce their profit margins and, for a shorter period of time, do not pass the increased import costs to the consumers. Apart from import prices, there can be very different other factors influencing inflation like wage increases. (iv) We also have to understand the reason for devaluation. If it is about attracting more investors and increasing competitiveness and economic growth, it can be an option. If they are just trying to find an appropriate exchange rate, the scenario is quite different and not leading to promising results.

When we summarize the possible effects, we can make the following conclusions. (i) Import prices increase, which leads to reduced real wages and consumption demand in the short run. Firms may postpone or completely halt investments as they are expecting further devaluations. (ii) The unexposed sector may register a loss in their profits and a higher level profit-to-GDP reduces private consumption. In those sectors which are exposed to devaluation structural changes can be delayed as the already strong companies may become even stronger. The higher profit level may also increase investments and R\&D. (iii) The interest rate increase in the short and in the long run as well leads to decreasing domestic demand, investment, and consumption.

\section{The Ethiopian economy with a special emphasis on the coffee sector}

Ethiopia, officially the Federal Democratic Republic of Ethiopia, is located in the Horn of Africa and has a strategic location. It is close to the Middle East and borders Eritrea, Somalia, Kenya, South Sudan, Sudan, and Djibouti. Ethiopia is the second most populous country in Africa and the most populous landlocked country in the world with a population of 102 million in 2016 (World Bank, 2018). The country occupies a total area of 1,100,000 square kilometers and its largest city is the capital, Addis Ababa.

Recently, Ethiopia experienced a massive economic growth and has become the fastest growing economy in the region. However, it is still one of the poorest with a per capita income of 783 USD (World Bank, 2018). Economic growth remained resil- 
ient in $2016 / 17^{2}$ despite the fact that the global prices for commodities are still weak and some pastoral regions are hit by droughts. Output has grown 9 percent partly because of the recovery in the agricultural sector and the 16 percent growth of the industrial sector. In the country, we can see a significant investment in infrastructure and manufacturing. The external current account deficit in 2016/17 narrowed due to lower imports but exports remained stagnant. The recent current account deficit is 8.2 percent of the GDP. Unfortunately, export revenues rose only 2.9 percent but coffee export volumes increased after supply-enhancing market reforms. Foreign direct investment (FDI) increased remarkably by almost 28 percent mainly because of the elevated investors' interest in industrial parks and privatization proceeds. However, international reserves dropped to 3.2 billion USD, which represents 1.8 months of prospective imports of goods and services (World Bank, 2018). The Ethiopian economy is a mixed and transition economy with a large public sector as the government slowly and steadily privatizes the state-owned businesses and moves closer to a market economy. The agricultural sector is still important in the economy (36.5\%), but recently, the share of the service sector has increased remarkably (42.2\%). The industrial sector represents 22.2 percent of the Ethiopian GDP (IMF, 2018).

In the year of 2016, Ethiopia exported 3.13 billion USD and this made the country the $117^{\text {th }}$ largest exporter in the world. During five years between 2011 and 2016, the exports of Ethiopia increased at an annualized rate of 1.7 percent from 2.88 billion USD in 2011 to 3.13 billion USD in 2016. Ethiopia exports coffee (24\%), other oily seeds (15\%), dried legumes (7.9\%), cut flowers (5.5\%), gold (13\%), gas (5.3\%), sheep, and goat meat (3.1\%). As for the imports, Ethiopia imported 17.9 billion USD which made the country the $75^{\text {th }}$ largest importer in the world. In the same period, the imports of Ethiopia increased at an annualized rate of 14.7 percent, from 8.38 billion USD in 2011 to 17.9 billion USD in 2016. Ethiopia imports refined petroleum (10.1\%), planes, helicopters and spacecrafts (3.6\%), packaged medicaments (3.6\%), delivery trucks $(3.3 \%)$, mixed mineral and chemical fertilizers (2.8\%), and gas turbines (2.3\%). (UN COMTRADE, 2018) Ethiopia exports mainly to China (14\%), Switzerland (11\%), the Netherlands (10\%), Saudi Arabia (9.2\%), the United States (7.4\%), and Germany (6.1\%). Ethiopia imports mostly from China (30\%), the United States (8.6\%), India (7.3\%), Kuwait (5.6\%), Italy (3.9\%), and Turkey (3.2\%). When it comes to trade openness, Ethiopia's value (value of export and import per GDP) was 28.55 percent in 2016 (UN COMTRADE, 2018). Agricultural commodities gave almost 80 percent of the export earnings in 2016/17 and the share of capital goods, fertilizer, and petroleum products was 66 percent in the same year. With these numbers, it is clear that Ethiopia

\section{Recently, Ethiopia experienced a massive economic growth and has become the fastest growing economy in the region. However, it is still one of the poorest with a per capita income of 783 USD.}


mainly exports agricultural commodities with high price elasticity of demand and imports products (capital goods, petroleum products, and fertilizers) with low price elasticity of demand.

Based on the export structure, it has become also clear that coffee production has an important place in the Ethiopian economy. Coffee is Ethiopia's most important export crop and the country is the biggest exporter in Africa accounting for 3 percent of the global coffee trade (ICO, 2014; Minten et al., 2017). Adugna et al. (2008) argue that the Ethiopian coffee is valuable in the global markets because it is of the Arabica type and because of its unique taste. However, we have to point to the fact that the Ethiopian coffee sector is underperforming as the coffee yields are low. The yields are higher in Uganda and only a bit lower in Rwanda and Kenya (Technoserve, 2014). When we compare these numbers with the major Latin American producers, the Ethiopian yields are only one-half and one-third of the level achieved in these countries. Technoserve (2014) argues that Ethiopian farmers obtain a smaller share of export prices compared to most other countries' farmers, and Ethiopian farmers earn the lowest share of the export price, at 60 percent of the export value. Shares in other countries range from 70 percent in Kenya to 90 percent in Brazil. Minten et al. (2017) highlight that coffee exports from Ethiopia have performed well over the last decade but when we compare 2010/11 (879 million USD) and 2016/17 (897 million USD), the numbers are not convincing (ICO, 2018). Most of the increase is related to the significant rise in the international prices of coffee (ICO, 2014). Minten et al. (2017) highlight the fact that while quantities exported from Ethiopia increased over the last decade, they were only 18 percent higher in 2013/14 compared to ten years earlier. It happened because in 2010 and 2013 we saw a decline in the price of coffee in the international market which challenged coffee exporters. The Ethiopian government incentivized the exporters to increase the volume of exports because earnings had stagnated for many years. There has been a large increase in national coffee production but this has been mostly the result of the increasing expansion of the coffee area, rather than through yield increasing. As it was released by a National Planning Commission report (NPC, 2016), the volume of exported coffee hit a record of 200,000 tons for the first time since 2014/15 but the export earnings did not meet the one-third of the set target. In the period of the first Growth and Transformation $\mathrm{Plan}^{3}$, the government wanted to generate an annual average of 783.3 million USD revenue from coffee export. Unfortunately, they reached only 61.4 percent of the target. It is also interesting that about half of the production is consumed within Ethiopia (Minten et al., 2017) but coffee accounts for up to 30 percent of the total export revenue (CSA, 2018a). So mainly this sector is targeted with the currency devaluation of 2017 and it would be interesting to see how this monetary policy tool succeeds.

4. The history of devaluations in Ethiopia and their impacts on the coffee sector The Ethiopian Birr (ETB) was introduced in 1945 and during the imperial regime, they used a fixed exchange rate policy with the official exchange rate of 2.5 ETB 
per USD. Then in the 1970s, two devaluation rounds came. During the Derg and before the EPRDF (Ethiopian People's Revolutionary Democratic Front) regimes Ethiopia still used the fixed exchange rate system with an official exchange rate of 2.07 Ethiopian Birr (ETB) per USD. Later it was the EPRDF which turned to devaluing the currency. Kidane (1994), for example, argued that owing to some exchange rate policy management problems in the 1970s and 1980s, the ETB was overvalued, causing trade and public budget deficits. Others like Taye (1992) and Ghura and Grennes (1993) indicated that in light of the unofficial market rate and other relevant measures of misalignment, the official value of the ETB since the 1970s was only about half or less of the unofficial market rates. At that time Ethiopia proved to be a textbook case as exports and domestic production were discouraged by the low price of the imported products. The shortage of hard currencies (mainly USD) was also rampant and only few people had the possibility to enter the foreign exchange market.

As it was observed in other countries as well (Milas - Otero, 2003), the unofficial or parallel exchange rate started to appear in the whole country. The result was obvious: by the mid-1980s, the unofficial rate reached 6 or 7 ETB per USD. (The official exchange remained unchanged at 2.07 ETB.) In the year of 1992, Ethiopia decided to devaluate the national currency to 5 ETB per USD. (This was a remarkable devaluation with the magnitude of 141.5 percent.) As Taye (1999) argued, the devaluation of the exchange rate was expected to increase output by giving a boost to the export sector and increase domestic production. 1992 was a milestone for the country as they abandoned the fixed exchange rate system and turned to the flexible one with the aim of controlling overvaluation. They wanted to gradually depreciate the ETB every single year by a given percentage. The first results were promising as the gap between the unofficial and official rate decreased in comparison with the period when the exchange rate had been fixed. However, in the fiscal years of 2007/08, 2009/10, and 2010/11, the rate of depreciation reached -so far- never-seen heights. In 2010, Ethiopia devalued the birr by 23.7 percent, and following the 2010 devaluation, the monetary authorities also allowed the unsterilized accumulation of foreign exchange reserves arising from the ensuing rise in exports and this contributed to additional inflation (inducing a growth penalty of 0.3 percentage points in the late 2000s) (Moller-Wacker, 2017). As the IMF (2010) and the NBE (2009) argued, these huge devaluations were expected to decrease overvaluation and increase competitiveness. After 2010, the Ethiopian currency was depreciating gradually and in 2016 it reached the exchange rate of 21.26 ETB per USD.

On October 9, 2017, Ethiopia's President, Mulatu Teshome claimed that earning foreign exchange became the issue of life and death for Ethiopia. One day later, on October 10, 2017, the National Bank of Ethiopia (NBE) devalued the ETB by 15 percent with immediate effect. The new exchange rate was 26.91 ETB per USD and since then the government has been counting on improved export numbers, decreased imports, and a narrower trade deficit. Also, in the hope of easing the inflationary pressures, the authorities have raised the key interest rate by 2 percent 
to 7 percent. In the followings, we are going to point to the argumentation of Bonsa (2017) when understanding the possible effects of devaluation.

As we could see in the theoretical part, the postdevaluation inflation pressures start to build up through two separate channels. (i) As the domestic currency is cheaper in the foreign exchange market, foreigners could purchase the locally made goods at a lower price, which leads to improved competitiveness. If Ethiopia has a larger stock of exportable goods than the quantity of exports, it will consequently increase its presence in the world market. New orders will give a boost to production and the relevant activities and after a time more investments and expenditure would be needed. At this point, it is quite obvious that inflationary pressures appear. (ii) The second effect is the price increase owing to imports. It is obvious that devaluation makes imported products more expensive in the local markets.

As it is clear from Figure 1, the inflation rate jumped from 8.14 percent (2010) to 33.22 percent (2011) and it remained quite high in 2012 as well with 22.78 percent. $^{4}$ So the immediate effect of the 2010 devaluation was a remarkable rise in the inflation rate. As Bonsa (2017) argues, the data stemming from the World Bank are quite conservative and the effects of the 2010 devaluation resulted in about a 40 percent increase in inflation.

The current Ethiopian government is well aware of this fact and in 2017 they turned to increasing the key interest rate in order to dispel the current inflation fears. (It is quite an unusual move in the international literature.) However, Bonsa (2017) highlights the fact that a slight increase (like 2 percent) in the interest rate is too

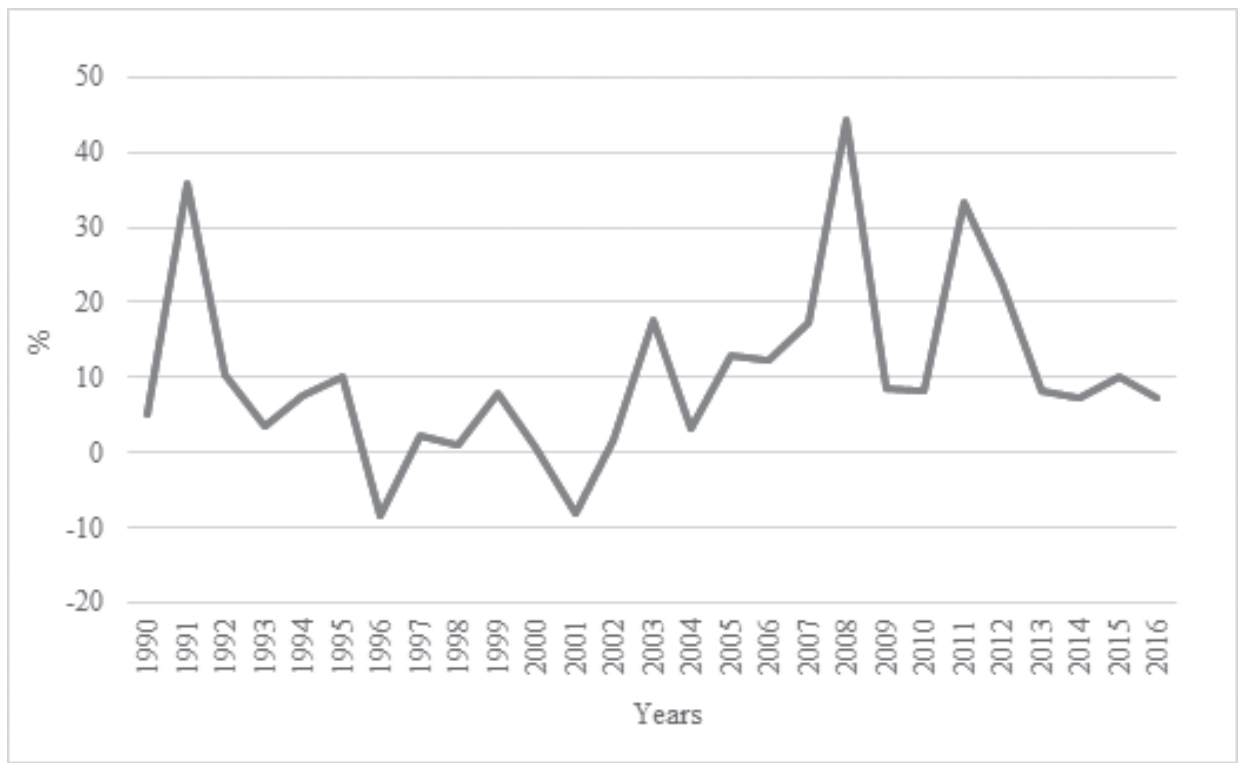

Figure 1. Inflation Rates (Consumer Prices) in Ethiopia (1990-2016)

Source: World Bank (2018) 
small to stop the inflationary pressures. It indeed might be a small step but finally the government admits that devaluations lead to inflation and they show certain signs of treating or solving this problem.

We have to point to a second, much more serious issue as well. First of all, as interest rates increase, the willingness to invest more simply evaporates. Secondly, those imported products (e.g., semi-prepared goods and services) which would be vital for boosting export production also become much more expensive. So, taking these two measures into consideration, we can easily detect contradictions.

In the theoretical part, we could have a more nuanced picture on the effects of devaluation on export performance and now we are still going to focus on the Ethiopian case and the impacts of the devaluation of 2010. However, we should bear in mind the argument of Bonsa (2017), according to which behind every devaluation is the ultimate policy target of improving trade deficit.

When we take into consideration the date of Figure 2, it is quite clear that the trade deficit in Ethiopia has increased quite remarkably since 1997. For us, the year of the last devaluation (2010) is crucial, so we compare the pre- and postdevaluation tendencies. Export revenues have increased from 2 billion USD in 2010 to 6 billion USD in 2014. Total merchandise export in 2010/11 increased by 37 percent to 2.75 billion USD in comparison with the previous year. The rise of 841.8 million USD was largely due to the 59.3 percent growth in coffee export earnings. This explains the rise from 26.4 percent (2009/10) to 30.6 percent (2010/11) in the share of coffee in total exports (NBE, 2018). The NBE annual reports (NBE, 2011; 2012) point to

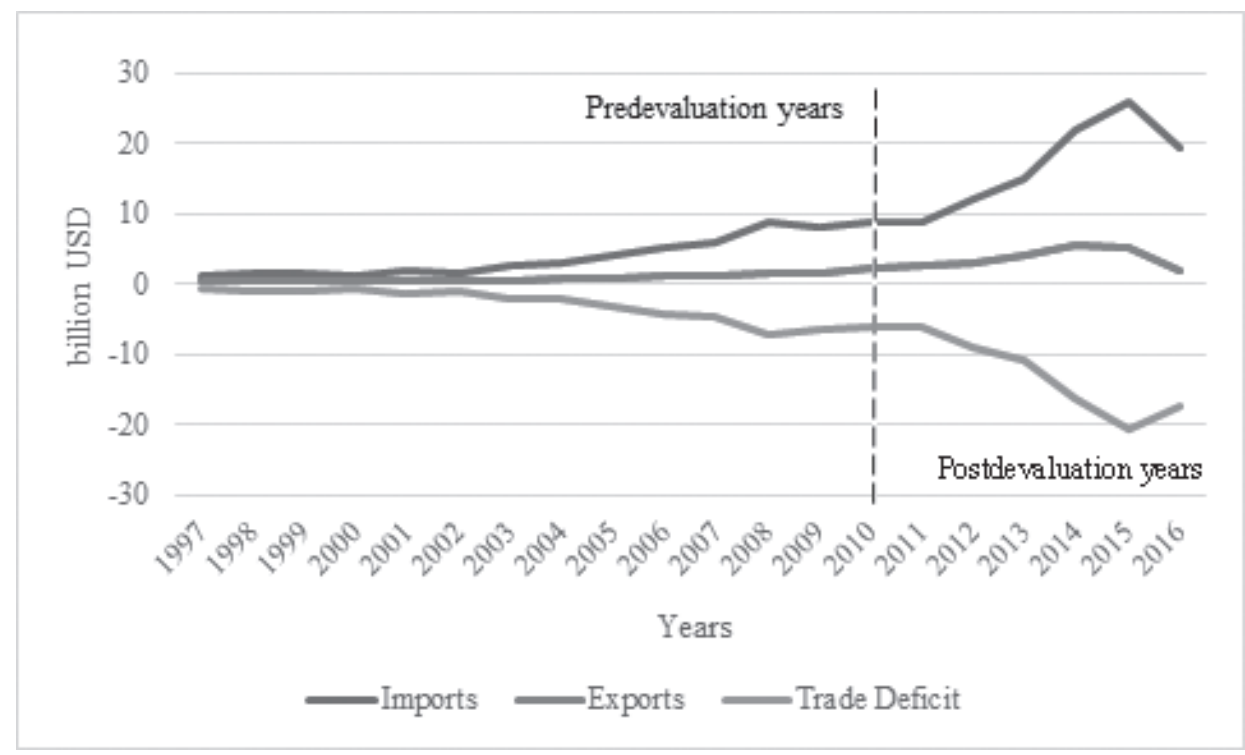

$\bigwedge$ Figure 2. Ethiopia's Trade Performance (1997-2016)

Source: World Bank (2018)

Szabolcs Pasztor: The New Wave of Currency Devaluations... 
the fact that there was an increase of export earnings of gold (64.1\%), live animals $(63 \%)$, leather and leather products $(84.1 \%)$, and meat and meat products $(86.2 \%)$ as well, and as a consequence, the share of export of goods in GDP improved to 10 percent from 6.7 percent in 2009/10. Later, there were protests in Ethiopia (triggering protests in Amhara regional state) and export numbers sharply declined by 2016 and reached again 2.91 billion USD (representing a 5.8 percent increase compared to 2010/11). Bonsa (2017) calls our attention to the fact that the figures are given in nominal terms and the effect of inflation is not taken into account. As the cumulative change in the general price level from 2010 to 2016 was 2.24, the country experienced a more than two-fold increase in prices of goods and services in just six years. In real terms, Ethiopia's export revenues in 2016 were less than $50 \%$ of the amount earned in 2010. It is also very telling that the coffee sector experienced the lowest increase of export earnings, a fact to be discussed later (NBE, 2012; 2018).

As far as imports are concerned, the bills decreased by 0.2 percent in 2010/11 in comparison with the previous year and reached 8.25 billion USD. This was largely because of the reduction of raw materials (13.5 percent) and capital goods ( 8.8 percent) imports. The share of imports in the GDP rose insignificantly to 29.6 percent from 27.8 percent. Owing to the fact that the total exports grew significantly and the total imports were reduced to a much lesser extent, the current account deficit in 2010/11 narrowed by 12.1 percent compared with the preceding fiscal year. Apart from the annual changes, it is also visible that expenditure on imports remarkably increased from 9 billion USD in 2010 to 26 billion USD in 2015 which is a three-fold increase. Based on the export and import tendencies, we can claim that Ethiopia's current trade surplus deteriorated and rose from about 6 billion USD in 2010 to 17 billion USD in 2016, which is also a three-fold increase. The share of the agricultural commodities of export earnings was 75 percent in 2010/11 and 80 percent in 2016/17. In the case of capital goods, fertilizers, and petroleum products, we have seen a decline from 68.4 percent in 2010/11 to 66 percent in 2016/17 (NBE, 2012; 2018).

Taking into consideration the whole period until 2017, the devaluation of 2010 was very far from being successful as export earnings increased by 5.8 percent only and the total merchandise import almost doubled and reached 15.8 billion USD in 2016/17. The current account deficit has increased by 134.5 percent since 2010 and reached 12.9 billion in 2016/17 (NBE, 2018).

When trying to answer these tendencies, we have to point to the fact that the current Ethiopian export policies actively discriminate against the country's main export product, coffee (Bonsa 2017). The author also highlights that the current export policy encourages brand new sectors which contribute to the overall export growth to a much lesser extent. Also, we have to confirm again that Ethiopia's imports are mostly essential products (e.g. petrol, semi-prepared goods, fertilizers, intermediate inputs, etc.). When the government promotes large public infrastructural projects, the import bill increases significantly, as capital goods are imported. As a result, the imported items become (unnecessarily) more and more expensive instead of being replaced by locally made products. Also, the discrepancies between trade value and 
quantity would have far-reaching implications as the exported goods are made cheap and more is needed to earn about the same export revenue. In addition, consumers pay more for the same quantity of consumer or capital goods imported. In the light of the 2010 devaluation and learning from the experience, our focus should be shifted to the 2017 one, but given the narrow time frame, only preliminary results are available.

The first numbers are promising as the Ethiopian Commodity Exchange (2018) announced that it traded coffee worth 9 billion ETB in the first half of the current fiscal year. This figure is 62 percent higher than that of the same period in the last fiscal year. The first results are indeed eye-catching as the export proceeds from coffee hit a record high, reaching 435 million USD ( 25 percent increase) in the first half of the current Ethiopian fiscal year (102,000 tons of coffee) (ERCA, 2018). It is the highest increase since 2012 and surpasses, by 22 percent, the quantity sold overseas in the same period in the last fiscal year (Hailu, 2018). It is interesting that the highest export revenue the country earned from coffee was recorded in the first half of 2015/16 with 329 million USD. This year's (2018) target is 1.14 billion USD and there are ambitious plans for 2019/20 with a target of 2.2 billion USD. More companies are getting involved in the sector as there used to be 214 companies and 21 are added. However, it is quite likely that a rise in the global commodity price is behind as a supply shortage started two years ago. The price of the coffee rose in the past two years (17.5 percent annual increase) (NBE, 2018).

However, coffee exporters argue that the improvement in revenues is driven by the rise in global commodity prices. According to the ICO (2018), the supply limitations which started two years ago, continued in 2017 as well. The price of coffee has seen a steady rise in the past two years and showed an average of 17.5 percent annual growth.

When it comes to inflation, not so many were surprised when it started to rise after the devaluation of October 2017. According to the CSA (2018b), the annual inflation rate grew by 12.2 percent in comparison with the same period last year and the monthly inflation rose by 0.2 percent between September and October 2017. The EBR conducted an informal market evaluation which confirmed the price surge of imported commodities and locally produced goods (EBR, 2018). The inflation rate rose to 14.7 percent in June 2018 from 13.7 percent in May (CSA, 2018b). Clothes, footwear, construction, and furniture items showed a significant rise in price last month. Cereals, dairy products, and vegetable items pushed the food inflation rate up. While food inflation reached 17.9 percent, the non-food component of inflation increased to 11.1 percent. The rate, which is almost 6.7 percentage points higher than 
the target set by the government, is the highest since February 2018. It is well-known that the inflation rate has been in double-digit numbers since August 2017 but the indicator started to show a quick pace since the effectiveness of the devaluation of ETB in October 2017 (CSA, 2018b). There is one more remarkable thing related to the recent monetary tendencies in Ethiopia as the gap between the official and the parallel exchange markets dwindled to 20 cents, which is the lowest in two decades. According to an assessment by the EBR (2018), the USD is exchanged for 27.3 ETB at the official market, the parallel market buys a dollar for 27.50 ETB.

Apart from these immediate effects, taking into consideration the main features and bottleneck of the Ethiopian export and coffee sector is more important when drawing final conclusions. Eshetu (2017), for example, argues that the first alternative policy for devaluation is boosting export performance through the rise in export productivity and diversification. The government may stimulate export diversification in the area of agriculture, agro-investment and agro-allied industries, and mining industries, which will improve the country's trade balance and foreign exchange earnings. According to Eshetu (2017), the second alternative policy to devaluation is to give due attention to the import-competing industries (e.g., chemical industries, cement factories, steel factory, and textile factories). This would help the Ethiopian trade balance improvement by decreasing dependence on imported goods.

Based on the theoretical part and the experiences of the previous devaluations, it seems that devaluation gives with one hand (exports) and takes with the other hand (imports) so the real effect on trade balance depends on the net effect. When a country is export-dependent, devaluation improves the trade balance and leads to output growth. However, in cases like Ethiopia, when the country is import-dependent, devaluation might aggravate the situation. Eshetu (2017) claims that devaluation has a positive impact once the country establishes export-oriented firms and international markets. Ethiopia first needs to import capital goods and when the production gets its way, devaluation makes sense. Among officials, it is widely accepted that coffee production, its value, and marketing chains need to improve on a massive scale. Realizing this, the parliament amended a proclamation in 2017 which is clustered around the production, the marketing, and the quality of coffee. (Proclamation No. 1051-2017 Coffee Marketing and Quality Control, 2017) The focus is partly on addressing the issues of the extended value chain and the widespread illegal trade in the sector. The proclamation also aims to incentivize coffee growers and exporters. Mehare and Edriss (2013) argue that instead of focusing on the volume of exports, the focus should be on real benefits for the country. They recommend value addition and as a consequence price increase before exporting. In this way, they point to rewarding the factors of production reasonably.

\section{Conclusions}

As the theoretical part concluded, the issue of currency devaluations is far from settled as the short- and long-term impacts are different on various economies. Still, Ethiopia has been trying to boost the export (coffee) sector with the help of this mea- 
sure. Before 2017, the previous devaluation rounds did not bring success and taking those effects and the current conditions into consideration, it is very unlikely that the export sector (and the coffee sector within) will be transformed and made competitive. Increasing import bills are quite likely and a further widening trade balance also. The current coffee sector in Ethiopia is burdened with a number of problems and solving them would be the first step to boost competitiveness. Increasing the value-added component, having a technological transformation, and reaching higher yields are definitely needed before devaluations. A less competitive sector coupled with regular devaluations gives only partial success and does not solve the major problems in the industry. It seems that decision-makers have to find the appropriate steps according to which devaluations are only secondary.

\section{Notes}

1 Like in most of the developing countries, there are two economies in present-day Ethiopia. There is the enclave economy with strongly interconnected domestic and foreign firms which are highly sophisticated. They jointly control the commanding heights of the Ethiopian economy. The rest of the economy is a traditional one where ordinary Ethiopians struggle to survive and make ends meet (Bonsa, 2017).

2 In Ethiopia, the fiscal year ends on July 7 of the calendar year.

3 The Growth and Transformation Plan (GTP) was a five-year plan made by the Ethiopian government in the hope of improving the economy and reaching an annual increase of 11-15 percent of the GDP. The plan sets numbers to be reached by most of the sectors of the economy (MOFED, 2018).

4 In August 2011, the inflation rate was 41 percent (NBE, 2018).

\section{Bibliography}

- Acar, M. (2000). Devaluation in Developing Countries: Expansionary or Contractionary? Journal of Economic and Social Research 2 (1), 59-83.

- Acharya, S. (2010). Potential Impacts of Devaluation of Nepalese Currency: A general equilibrium approach. Economic Systems 34 (4), 413-436.

- Adugna, G., Bellachew, B., Shimber, T., Taye, E. and Kufa, T. (2008). Coffee Diversity and Knowledge. Ethiopian Institute of Agricultural Research. Addis Ababa, Ethiopia.

- Agénor, P. R. (1991). Output, devaluation and the real exchange rate in developing countries. Weltwirtschaftliches Archiv 127 (1), 18-41.

- Akinlo, E. A. (1996). Improving the Performance of the Nigerian Manufacturing sub-sector after Adjustment. Nigerian Journal of Economic and Social Studies 3 (9), 91-111.

- Al-Abdelrazag, B. (1997). Does Devaluation Improve Jordan's Trade Balance (1969-1994). Abath Al-varmouk 3 (1), 65-72.

- Alessandria, G., Pratap, S. and Yue, V. (2013). Export Dynamics in Large Devaluations. International Finance Discussion Papers 1087, Board of Governors of the Federal System (US) https://www.federalreserve.gov/pubs/ifdp/2013/1087/ifdp1087 [07.16.2018]

- An, L., Kim, G. and Ren, X. (2014). Is devaluation expansionary or contractionary? Evidence based on vector autoregression with sign restrictions. Journal of Asian Economics 34 (10), 27-41.

- Backus, D., Patrick K. and Kydlad, F. (1994). Dynamics of the Trade Balance and the Terms of Trade: The J-Curve? American Economics Review 84, 84-103. 
- Bonsa, J. (2017). Devaluing the Birr: Doing the Same Thing over and over again and expecting a different outcome. Addis Standard. http://addisstandard.com/economic-analysis-devaluingbirr-thing-expecting-different-outcome/ [06.10.2018]

- Central Statistical Agency of Ethiopia (CSA). (2018a). Ethiopia Country Stat - Metadata. http://193.43.36.162/home.aspx?c=ETH\&p=me [07.30.2018]

- Central Statistical Agency of Ethiopia (CSA). (2018b). Consumer price index in Ethiopia. http://www.csa.gov.et/ehioinfo-internal?start=5 [07.30.2018]

- Dornbusch, R. (1973). Exchange Rate Economies. Brooking Papers on Economic Activity.

- Edwards, S. (1986). Are Devaluations Contradictory? The Review of Economics and Statistics 68 (3), 501-508.

- Erixon, L. (2007). Even the bad times are good: a behavioral theory of transformation pressure. Cambridge Journal of Economics, 31 (3), 327-348.

- Eshetu, F. (2017). Birr devaluation and its effect on trade balance of Ethiopia: An empirical analysis. Journal of Economics and International Finance 9 (11), 103-119.

- Ethiopian Commodity Exchange (ECX). (2018). ECX Coffee Contract. http://www.ecx.com. et/downloads/Contracts/Coffee/CoffeeContracts.pdf [08.01.2018]

- Ethiopian Revenues and Customs Authority (ERCA). (2018). Latest News on exports. http:// www.erca.gov.et/ [08.01.2018]

- Gala, P. (2007). Real exchange rate levels and economic development: theoretical analysis and econometric evidence. Cambridge Journal of Economics 32 (2), 273-288.

- Ghura, D. and Grennes, T. (1993). The Real Exchange Rate and Macroeconomic Performance in Sub-Saharan Africa. Economic Development and Cultural Change 42, 155-174.

- Girton, L. and Roper, D. (1977). A Monetary Model of Exchange Market Pressure Applied to the Canadian Postwar Experience. American Economic Review 67 (4), 537-548.

- Goldberg, L. S. (1990). Nominal Exchange Rate Patterns: Correlations with entry, exit and investment in US industry. National Bureau of Economic Research Working Paper No. 3249, January 1990.

- Hailu, S. (2018). October's Devaluation. Ethiopian Business Review 15 March 6 (58), 13-18.

- ICO (Internatioal Coffee Organization). (2018). Trade Statistics Tables. http://www.ico.org/ trade_statistics.asp?section=Statistics [07.20.2018]

- ICO (International Coffee Organization). (2014). Strenghtening the Global Coffee Sector through International Cooperation. http://dev.ico.org/documents/cy2014-15/annual-review2013-14-electronic-e.pdf [08.01.2018]

- IMF. (2010). The Federal Democratic Republic of Ethiopia: A Second Review of the Arrangement under Exogenous Shocks Facility. https:/www.imf.org/en/Publications/CR/ Issues/2016/12/31/The-Federal-Democratic-Republic-of-Ethiopia-Second-Review-of-theArrangement-under-the-24375 [06.12.2018]

- IMF. (2017). Regional Economic Outlook. Sub-Saharan Africa: Fiscal Adjustment and Economic Diversification. October 2017. https://www.imf.org/en/Publications/REO/SSA/ Issues/2017/10/19/sreo1017 [05.10.2018]

- IMF. (2018). World Economic Outlook. Cyclical Upswings, Structural Change. April 2018. http://www.imf.org/en/Publications/WEO/Issues/2018/03/20/world-economic-outlookapril-2018 [05.21.2018]

- Imoisi, A. I. (2012). Trends in Nigeria's Balance of Payments: An empirical analysis from 1970-2010. European Journal of Business and Management IISTE, USA 4 (21), 210-217.

- Johnson, H. G. (1967). Towards a General Theory of the Balance Payments. International Trade and Economic Growth: Studies in Pure Theory. Cambridge Mass, Harvard University Press.

- Kidane, A. (1994). Indices of Effective Exchange Rates: A Comparative Study of Ethiopia, Kenya and the Sudan. African Economic Research Consortium. November 1994. 
- Krueger, A. O. (1983). Exchange rate determination. Cambridge University Press, Cambridge.

- Krugman, P. and Taylor, L. (1978). Contradictory effects of Devaluation. Journal of International Economics 8, 445-456.

- Manova, K. (2013). Credit Constraints, Heterogeneous Firms, and International Trade. Review of Economic Studies 80, 711-744.

- Meade, E. (1988). Exchange Rates, Adjustment, and the J-Curve. Federal Reserve Bulletin 74, 633-644.

- Mehare, A. and Edriss. A. K. (2013). Evaluation of the Effect of Exchange Rate Variability on the Export of Ethiopia's Agricultural Product: A Case of Coffee. Margin - The Journal of Applied Economic Research 7 (2), 171-183.

- Milas, C. and Otero, J. (2003). Modelling official and paralell exchange rates in Colombia under alternative regimes: a non-linear approach. Economic Modelling, 20 (1), 165-179.

- Miles, A. (1979). The Effects of Devaluation on the Trade Balance and the Balance of Payments: Some New Results. Journal of Political Economy 87 (3), 600-620.

- Ministry of Finance and Economic Cooperation (MOFED). (2018). GTP Main Document. http://www.mofed.gov.et/web/guest//gtp-policy-matrix-vol-2?inheritRedirect=true [07.25.2018]

- Minten, B., Dereje, M., Engida, E. and Kuma, T. (2017). Coffee value chains on the move: Evidence in Ethiopia. Food Policy, (forthcoming)

- Moller, L. C. and Wacker, K. M. (2017). Explaining Ethiopia's Growth Acceleration - The Role of Infrastructure and Macroeconomic Policy. World Development August 2017 96, 198 215.

- Musila, J. W. and Newark, J. (2003): Does Currency Devaluation Improve the Trade Balance in the Long Run? Evidence from Malawi. African Development Review 15 (2-3), 339-352.

- National Bank of Ethiopia (NBE). (2009): Annual Report 2009/10.

- http://www.nbebank.com/pdf/annualbulletin/Annual\%20Report\%202009_2010/Annual\%20 Report\%202009_2010.pdf [05.20.2018]

- National Bank of Ethiopia (NBE). (2011). Annual Report 2010/11. https://www.nbe.gov.et/ publications/annualreport.html [05.20.2018]

- National Bank of Ethiopia (NBE). (2012). Annual Report 2011/12. https://www.nbe.gov.et/ publications/annualreport.html [05.20.2018]

- National Bank of Ethiopia (NBE). (2018). Statistics - Monthly Macroeconomic https://www. nbe.gov.et/statistics/monthlyindicators.html [05.20.2018]

- Nizard, R. (2018). Currency Risk in Africa: easing in 2018 but reserves have melted. Coface Economic Publications, April 2018. Paris, France.

- NPC (National Planning Commission). (2016). Second Growth and Transformation Plan, http://www.npc.gov.et/documents/101123/979b7e51-ea5d-4bad-b148-662eset06a612 [08.01.2018]

- Paul, S. (2006). Devaluation, Innovation and Prices. The International Trade Journal 20 (1), 75-83.

- Proclamation No. 1051-2017 Coffee Marketing and Quality Control. (2017). https://chilot. me/wp-content/uploads/2017/11/proclamation-no-1051-2017-coffee-marketing-and-qualitycontrol.pdf [05.20.2018]

- Ratha, A. (2010). Does Devaluation work for India. Economics Bulletin 30 (1), 247-264.

- Reinhart, C. M. (1995). Devaluation, Relative Prices, and International Trade: Evidence from Developing Countries. IMF Staff Papers 42, June 1995, 290-312.

- Taye, H. K. (1992). Is the Ethiopian Currency (birr) Overvalued? Paper presented for the Second Annual Conference on the Ethiopian Economy, Addis Ababa, Ethiopia.

- Taye, H. K. (1999). The Impact of Devaluation on Macroeconomic Performance: The Case of Ethiopia. Journal of Policy Modeling 21 (4), 481-496. 
- Technoserve. (2014). Ethiopia: A Business Case for Sustainable Coffee Production. Mimeo.

- Tybout, J., Gauthier, B., Navaretti, G. B. and De Melo, J. (1997). Firm-Level Response to the CFA Devaluation in Cameroon. Journal of African Economies 6 (1), 3-34.

- UN COMTRADE. (2018). International Trade Statistic Yearbook Vol. I-II. https://comtrade. un.org/pb/downloads/2016/VolI2016.pdf [08.01.2018]

- Williamson, J. (1983). The Open Economy and the World Economy. Basic Books, New York.

- World Bank (2018). The World Bank in Ethiopia - Overview. http://www.worldbank.org/en/ country/ethiopia/overview [07.01.2018]

- Zaidan, T. M. (1999). Does Devaluation Improve the Trade Balance of Iraq. OPEC Publications, 127-137.
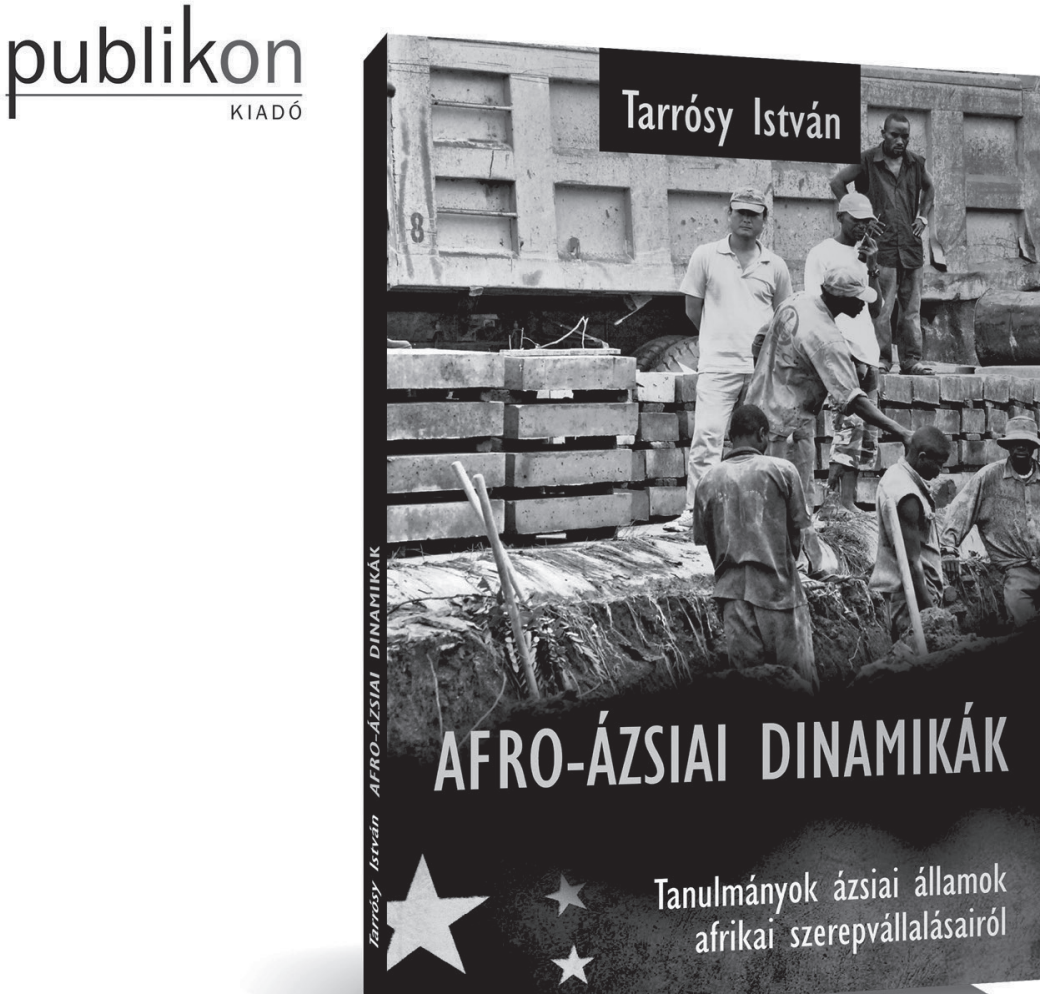

Tanulmányok ázsiai államok afrikai szerepvállalásairól

Tarrósy István

AFRO-ÁZSIAI DINAMIKÁK 